\title{
Early Continuous Renal Replacement Therapy in Cardiogenic Shock Patients with Severe Acute Kidney Injury Undergoing Extracorporeal Membrane Oxygenation
}

\author{
Yen-Chung Lin ${ }^{a}$ d $\quad$ Yi-Chun Lin ${ }^{e}$ Feng-Yen Lin ${ }^{b}, d \quad$ Chun-Ming Shih ${ }^{b}$ d \\ Mai-Szu Wu ${ }^{a, d}$ Tzen-Wen Chen ${ }^{a, d}$ Hsi-Hsien Chen ${ }^{a, d}$ \\ Nen-Chun Chang b, ${ }^{b}$ Nai-Wen Tsao ${ }^{c}$ Chun-Yao Huang ${ }^{\text {b, } d}$ \\ Divisions of a Nephrology and ${ }^{b}$ Cardiology, Department of Internal Medicine, and ${ }^{c}$ Division of \\ Cardiovascular Surgery, Department of Surgery, Taipei Medical University Hospital, \\ ${ }^{d}$ Department of Internal Medicine, School of Medicine, College of Medicine, Taipei Medical \\ University, and e Division of Endocrinology and Metabolism, Department of Internal \\ Medicine, Taipei City Hospital, Ren-Ai Branch, Taipei, Taiwan (ROC)
}

\section{Key Words}

Acute kidney injury · Continuous renal replacement therapy · Extracorporeal membrane oxygenation - Glomerular filtration rate

\begin{abstract}
Background: Continuous renal replacement therapy (CRRT) may benefit patients requiring extracorporeal membrane oxygenation (ECMO). However, the clinical benefits and timing of CRRT have not been fully elucidated for these patients. Methods: This study was conducted retrospectively at the Taipei Medical University Hospital between January 2008 and December 2010. We included patients who had Acute Kidney Injury Network (AKIN) stage 3 disease at the initiation of ECMO and subsequently underwent CRRT. We excluded patients aged $<18$ years or those who were chronic dialysis patients. Early dialysis was defined as receiving CRRT $<24 \mathrm{~h}$ after the initiation of ECMO. The primary outcome was mortality before weaning from ECMO. Results: The median age of the 15 patients included in the study was 72 years. The median interval between ECMO and CRRT was $16 \mathrm{~h}$. No significant difference in survival was observed between the early- and late-dialysis patients ( $p=0.58$, log-rank test). However, a trend toward a shorter mean duration of ECMO therapy was observed in the early-dialysis patients (124 vs. $169 \mathrm{~h}, \mathrm{p}=0.16$ ). The median follow-up glomerular filtration rate for the survivors was $38.9 \mathrm{ml} / \mathrm{min} / 1.73 \mathrm{~m}^{2}$. Conclusion: No survival benefit is conferred by the use of CRRT within $24 \mathrm{~h}$ after initiating ECMO in patients with severe acute kidney injury according to AKIN criteria.




\section{CardioRenal Medicine}

\section{Introduction}

Extracorporeal membrane oxygenation (ECMO) is a primary treatment modality for intractable hypoxemic respiratory and cardiac failure in neonates and infants [1]. The survival of adult patients with acute fulminant myocarditis [2], those receiving conventional cardiac massage because of cardiac arrest [3], and those with acute myocardial infarction complicated by cardiogenic shock is improved by ECMO treatment [4]. As a result, the number of adult patients undergoing ECMO is increasing worldwide [5].

Poor fluid management and pulmonary edema may cause a deterioration in cardiac and alveolar functions, thereby prolonging the duration of ECMO treatment [6] or decreasing patient survival [7]. Continuous renal replacement therapy (CRRT) using continuous venovenous hemofiltration $(\mathrm{CVVH})$ can effectively enhance the fluid balance during ECMO therapy $[8,9]$. An early initiation of CRRT has been reported to improve survival in postcardiotomy patients with acute renal failure [10] and allowed the removal of ECMO support [11]. Early use of CRRT may be an important therapeutic factor in the prevention of refractory fluid overload. However, a premature initiation of CRRT may be harmful to critically ill patients [12]. In a large cohort study in Asia, mortality was higher among ECMO patients receiving CRRT than in those receiving ECMO only [13]. For those not requiring chronic hemodialysis, chronic kidney disease (CKD) was a problem. Whether the early initiation of CRRT improves survival in hemodynamically unstable patients receiving ECMO is unclear.

We hypothesized that an early initiation of CRRT improves survival in patients receiving ECMO. Thus, we conducted a retrospective study of cardiogenic shock patients requiring venoarterial (VA)-ECMO who presented with severe acute kidney injury (AKI). The aim of our study was to determine whether an early initiation of CRRT increased successful weaning from ECMO and improved short-term survival in VA-ECMO patients with severe AKI.

\section{Subjects and Methods}

Study Design

In our retrospective cohort study, we analyzed the medical records of acute cardiogenic shock patients who received ECMO therapy at the Taipei Medical University Hospital. We reviewed ECMO patients who received CRRT and fulfilled the clinical criteria for Acute Kidney Injury Network (AKIN) stage 3 disease before the initiation of ECMO between January 2008 and December 2010. Patients aged $<18$ years and those who had undergone regular hemodialysis before receiving ECMO were excluded. Early dialysis was defined as receiving CRRT $<24 \mathrm{~h}$ after initiating ECMO, and late dialysis was defined as receiving CRRT $\geq 24 \mathrm{~h}$ after initiating ECMO.

The use of ECMO therapy was introduced to our hospital in January 2007. Our ECMO team included a single cardiovascular surgeon, two perfusionists, and one registered nurse. The ECMO equipment used in our hospital included a membrane oxygenator (Affinity NT Oxygenation Systems; Medtronic, Minneapolis, Minn., USA), a blood pump, an artificial heart (Medtronic BioConsole 560 System; Medtronic), and cannulation tubing. The use of CRRT was introduced to our hospital in January 2008. The CRRT procedure was administered via cannulation by a well-trained, registered nurse in the intensive care unit using a Prismaflex CRRT device (Gambro, Stockholm, Sweden). Central venous pressure (CVP) was routinely measured using an indwelling jugular catheter and a pressure manometer or transducer.

We recorded the clinical parameters and the laboratory data from blood biochemical analyses for all the patients included in our study. Our retrospective study was approved and monitored by the Institutional Review Board of Taipei Medical University. The need for informed consent was waived because patient privacy was not breached and our analysis did not influence clinical decisions related to the care of the patients included in our study. 


\section{CardioRenal Medicine}

\begin{tabular}{l|l}
\hline Cardiorenal Med 2014;4:130-139 \\
\hline DOI: 10.1159/000364835 & $\begin{array}{l}\text { (c) 2014 S. Karger AG, Basel } \\
\text { www.karger.com/crm }\end{array}$ \\
\hline
\end{tabular}

Lin et al.: Early Continuous Renal Replacement Therapy in Cardiogenic Shock Patients with Severe Acute Kidney Injury Undergoing Extracorporeal Membrane Oxygenation

Venoarterial Extracorporeal Membrane Oxygenation

In VA-ECMO, blood is drained from the inferior vena cava via an intravenous catheter (21 Fr) and returned to the common iliac artery ( $15 \mathrm{Fr}$ ). The use of VA-ECMO provides both cardiac and pulmonary support. It is used to maintain systolic blood pressure in patients with cardiogenic shock because of severe myocardial infarction or acute myocarditis. An ECMO flow rate of 2-3.5 l/min was used to provide adequate systemic circulation by maintaining a mean blood pressure at $>65 \mathrm{~mm} \mathrm{Hg}$.

We initiated VA-ECMO in patients with profound cardiogenic shock and those whose mean blood pressure could not be maintained $>65 \mathrm{~mm} \mathrm{Hg}$ with intravenous dopamine $(\leq 20 \mu \mathrm{g} / \mathrm{kg} / \mathrm{min})$. The ECMO machine was installed in either the emergency department or the catheterization room according to the urgency of hemodynamic instability. Acute dialysis was indicated in patients with (1) hyperkalemia (serum $\mathrm{K}^{+}$level $>5.7 \mathrm{mmol} / \mathrm{l}$ ) despite medical treatment, (2) oliguria (urine output $<200 \mathrm{ml} / 8 \mathrm{~h}$ ), (3) pulmonary edema as shown in plain X-ray films, (4) azotemia (blood urea nitrogen level $>80 \mathrm{mg} / \mathrm{dl}$ ), or (5) severe metabolic acidosis (blood gas $\mathrm{pH}<7.2$ ) despite medical treatment.

Definition of Early and Late Dialysis

The AKIN criteria for stage 3 AKI are (1) serum creatinine $>300 \%$ of the baseline level or absolute serum creatinine $\geq 354 \mu \mathrm{mol} / \mathrm{l}$ and (2) a urine output $<0.3 \mathrm{ml} / \mathrm{kg} / \mathrm{h}$ for $24 \mathrm{~h}$ or anuria for $12 \mathrm{~h}$. Early dialysis was defined as starting CRRT $<24 \mathrm{~h}$ after initiating ECMO, and late dialysis was defined as starting CRRT $\geq 24 \mathrm{~h}$ after initiating ECMO.

CVVH was used for CRRT during VA-ECMO dialysis by connecting an extracorporeal blood purification system to the prepump of the venous catheter of the ECMO machine. CVVH was performed with a blood flow rate of approximately $350 \mathrm{ml} / \mathrm{min}$, depending on the intervening pressure gradient, and a hemofiltration flow rate of $35 \mathrm{ml} / \mathrm{kg} / \mathrm{h}$. The replacement fluid was buffered with bicarbonate and administered undiluted at a dynamically adjusted rate to achieve the desired daily ultrafiltration volume. The default composition of the replacement fluid was $142 \mathrm{mEq} / \mathrm{l} \mathrm{Na}^{+}, 33 \mathrm{mEq} / \mathrm{l}$ bicarbonate, $1.4 \mathrm{mEq} / \mathrm{l} \mathrm{Mg}^{2+}$, and $2.6 \mathrm{mEq} / \mathrm{l} \mathrm{Ca}^{2+}$. The daily CVVH-VA-ECMO ultrafiltration rate and urine output were recorded for each patient.

\section{Criteria for ECMO Weaning and Outcome}

The ECMO team usually tapered the dose of the inotropic agents after ECMO initiation. When the dopamine and dobutamine dose was $<10 \mu \mathrm{g} / \mathrm{kg} / \mathrm{min}$, the left ventricular ejection fraction (LVEF) was $>40 \%$, or the CVP was $<12 \mathrm{~mm} \mathrm{Hg}$, weaning from ECMO was attempted by decreasing the blood flow rate to $<0.5 \mathrm{l}$ / $\mathrm{min}$. Weaning was considered successful only if the clinical presentation was stable for $5 \mathrm{~min}$. The removal of the ECMO equipment, including the ECMO catheter, from the patient $24 \mathrm{~h}$ after successful weaning in the intensive care unit was regarded as survival. We also measured the serum creatinine levels of the survivors 3 months after discharge.

\section{Laboratory Measurements}

Blood biochemical parameters were measured using the TBA-120FR Clinical Chemistry Analyzer (Toshiba, Otawara, Japan). Additional data obtained for each patient included age, chronic health conditions, the reason for ECMO initiation, the use of medications, and the acute physiology score of the Acute Physiology and Chronic Health Evaluation (APACHE II). We recorded the time sequence of ECMO and CRRT. The LVEF was routinely recorded using a transthoracic portable echocardiography device by the same cardiologist who acquired the baseline data upon admission. The inotropic equivalent was calculated as (milrinone $\times 15$ ) $+($ dopamine + dobutamine + epinephrine + norepinephrine + isoproterenol $) \times 100 \mu \mathrm{g} / \mathrm{kg} / \mathrm{min}$, based on the quantity of each drug used in micrograms.

The laboratory series included serum levels of sodium, potassium, and albumin as well as baseline, pre-CRRT, and pre-ECMO creatinine. The hemoglobin level, the white blood cell count, and the urine output rate before ECMO were also measured. The average ultrafiltration rate, the urine output rate during CRRT, the most recent measurements of CVP, and the systolic/diastolic blood pressure at the initiation of ECMO were recorded. The Chronic Kidney Disease Epidemiology Collaboration (CKD-EPI) equation was used to evaluate the estimated glomerular filtration rate (GFR) of the survivors 3 months after discharge as GFR $=141 \times \min (\mathrm{Scr} / \kappa, 1) \alpha \times \max (\mathrm{Scr} / \kappa, 1)-1.209 \times 0.993$ (age in years). The GFR of female and black patients was adjusted by multiplying their age by 1.018 or 1.159 , respectively, as described previously [14]. 


\section{CardioRenal Medicine}

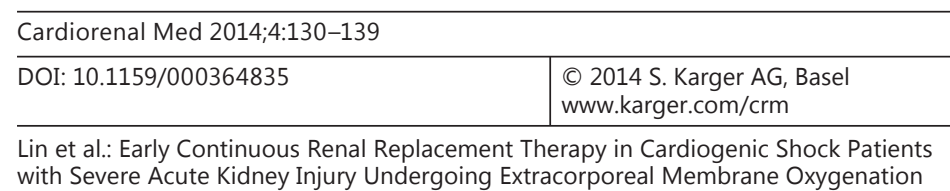

Lin et al.: Early Continuous Renal Replacement Therapy in Cardiogenic Shock Patients
with Severe Acute Kidney Injury Undergoing Extracorporeal Membrane Oxygenation

Statistical Analysis

The statistical analysis was performed using the Stata computer software version 12.1 (StataCorp, College Station, Tex., USA). The continuous data are expressed as means \pm standard deviations; they were analyzed using the Mann-Whitney $U$ test. The categorical variables were analyzed using $\chi^{2}$ tests. The KaplanMeier method was used to analyze the patient survival rate. A two-tailed $\mathrm{p}<0.05$ was considered to indicate a statistically significant difference between data sets.

\section{Results}

\section{Patient Characteristics}

Fifteen patients were enrolled in our study, 11 (73.3\%) of whom were men. Their median age was 72 years. Five (33.3\%) of the patients had type 2 diabetes, and $10(66.7 \%)$ of them had acute myocardial infarction-related cardiogenic shock. One patient had myocarditis, and 4 had undergone emergent cardiopulmonary resuscitation. The median interval between ECMO and CRRT was $16 \mathrm{~h}$, and 12 (80\%) of the patients received inotropic agents. Only 5 $(33.3 \%)$ of the patients were successfully weaned from ECMO. The baseline demographic characteristics are shown in table 1.

\section{Differences in Clinical Presentation between the Early- and Late-CRRT Groups}

With the exception of the interval between ECMO and CRRT (12 vs. $44 \mathrm{~h}, \mathrm{p}=0.001$ ) and the hemoglobin level ( 9.9 vs. $13 \mathrm{mg} / \mathrm{dl}, \mathrm{p}=0.01$ ), no significant differences in the following characteristics were observed between the early- and late-dialysis groups: age; duration of ECMO; baseline, pre-ECMO, or pre-CRRT levels of serum creatinine; LVEF; average ultrafiltration rate and urine output rate during CRRT; CVP levels, or APACHE II scores at the initiation of ECMO (table 2). Although the difference was not significant, the mean duration of ECMO was shorter for the early-dialysis group than the late-dialysis group (124 vs. $169 \mathrm{~h}$, $p=0.16$ ). Early dialysis did not correlate with higher rates of survival among the patients who were successfully weaned from ECMO therapy $(p=0.71)$.

\section{Survival Analysis}

The Kaplan-Meier analysis of early dialysis revealed no significant difference in shortterm cumulative patient survival compared with that after late dialysis ( $p=0.58$, log-rank test; fig. 1).

\section{Prognosis of Kidney Disease in the Survivors}

One of the 5 patients who were successfully weaned from ECMO died later because of septic shock. The median age of the 4 long-term survivors was 68.3 years, and $50 \%$ of them were men. The median duration of ECMO was $196 \mathrm{~h}$. Three of the 4 long-term survivors had CKD, with a median GFR of $38.9 \mathrm{ml} / \mathrm{min} / 1.73 \mathrm{~m}^{2}$ (table 3), and 1 of them required maintenance hemodialysis after discharge.

\section{Discussion}

In our study, early dialysis within $24 \mathrm{~h}$ of initiating ECMO in acute cardiogenic shock patients with AKIN stage 3 disease produced no significant improvement in survival compared with a late initiation of dialysis. The early-dialysis group had a median duration of ECMO that was only approximately $13 \mathrm{~h}$ shorter than that for the late-dialysis group, and the interval between ECMO and CRRT for the early-dialysis group was similarly shorter. The basic char- 
Lin et al.: Early Continuous Renal Replacement Therapy in Cardiogenic Shock Patients

Table 1. Demographic characteristics of the cardiogenic shock patients on VA-ECMO with AKIN stage 3 disease $(n=15)$

General characteristics

Age, years

$72(50-76)$

Male, n (\%)

$11(73.3)$

BMI

$25(19-28)$

Systolic blood pressure, $\mathrm{mm} \mathrm{Hg}$

$114(96-139)$

Use of intra-aortic balloon pump, $\mathrm{n}(\%)$

$12(80.0)$

ECMO, $\mathrm{h}$

$169(61-199)$

ECMO to CRRT, h

$16(11-44)$

Past history

Coronary artery disease, $\mathrm{n}(\%)$

$6(40.0)$

Type 2 diabetes, $\mathrm{n}(\%)$

$5(33.3)$

CKD, n (\%)

$9(60.0)$

Hypertension, n (\%)

$4(26.7)$

Reason for ECMO use

Acute myocardial infarction with cardiogenic shock, $\mathrm{n}(\%)$

Diffuse myocarditis with cardiogenic shock, n (\%)

$10(66.7)$

Out-of-hospital cardiac arrest, n (\%)

$1(6.7)$

$4(26.7)$

Laboratory values

Baseline serum creatinine, $\mathrm{mg} / \mathrm{dl}$

$1.2(1.0-2.5)$

Pre-ECMO serum creatinine, $\mathrm{mg} / \mathrm{dl}$

$2.6(1.9-3.9)$

Pre-CRRT serum creatinine, $\mathrm{mg} / \mathrm{dl}$

$3.6(2.8-5.1)$

Pre-ECMO urine output, $\mathrm{ml} / \mathrm{kg} / \mathrm{h}$

$70(10-320)$

LVEF, \%

$25(20-32)$

White blood cell count, $\times 10^{3}$ cells $/ \mu \mathrm{l}$

$13.2(0.9-2.3)$

Serum sodium, $\mathrm{mEq} / \mathrm{l}$

Serum potassium, $\mathrm{mEq} / \mathrm{l}$

$142(138-149)$

Hemoglobin, g/dl

$4.6(3.6-5.3)$

Albumin, g/dl

$11.2(9.8-13.0)$

$3(2.3-3.4)$

Clinical presentations

Inotropic equivalent dose, $\mu \mathrm{g} / \mathrm{kg} / \mathrm{min}^{\mathrm{a}}$

$28(11-43)$

Use of inotropics, n (\%)

$12(80.0)$

Pre-ECMO CVP level, $\mathrm{mm} \mathrm{Hg}$

$17(14-22)$

$25(22-33)$

$0.9(0.4-1.5)$

Average ultrafiltration rate during CRRT, $\mathrm{ml} / \mathrm{kg} / \mathrm{h}$

$0.1(0.06-0.1)$

Average urine output during CRRT, $\mathrm{ml} / \mathrm{kg} / \mathrm{h}$

$8(53.3)$

Cardiopulmonary resuscitation, $\mathrm{n}(\%)$

7 (46.7)

Outcome

Survival to weaning from ECMO, n (\%)

$5(33.3)$

Numeric variables are expressed as medians with 25 th-75th percentiles in parentheses.

${ }^{\text {a }}$ Inotropic equivalent $=[($ dopamine + dobutamine $)+($ milrinone $\times 15)+($ epinephrine + norepinephrine + isoproterenol) $\times 100]$ in $\mu \mathrm{g} / \mathrm{kg} / \mathrm{min}$ [14]

acteristics such as the disease severity and the laboratory variables at the initiation of ECMO, the ultrafiltration rate, and the urine output during CRRT were also similar between the early- and late-dialysis groups, whereas the interval between ECMO and CRRT and the hemoglobin level were not.

The prognosis of patients receiving ECMO who require CRRT is especially poor [15-17]. $\mathrm{Wu}$ et al. [13] reported that the latency between hospital admission and dialysis correlated 


\section{CardioRenal Medicine}

\begin{tabular}{l|l}
\hline Cardiorenal Med 2014;4:130-139 \\
\hline DOI: 10.1159/000364835 & $\begin{array}{l}\text { @ 2014 S. Karger AG, Basel } \\
\text { www.karger.com/crm }\end{array}$ \\
\hline $\begin{array}{l}\text { Lin et al.: Early Continuous Renal Replacement Therapy in Cardiogenic Shock Patients } \\
\text { with Severe Acute Kidney Injury Undergoing Extracorporeal Membrane Oxygenation }\end{array}$
\end{tabular}

with Severe Acute Kidney Injury Undergoing Extracorporeal Membrane Oxygenation

Table 2. Comparison of the characteristics and clinical presentations of the study population between the early- and latedialysis groups

\begin{tabular}{|c|c|c|c|}
\hline & Early dialysis $(\mathrm{n}=8)$ & Late dialysis $(\mathrm{n}=7)$ & $\mathrm{p}$ \\
\hline \multicolumn{4}{|l|}{ General characteristics } \\
\hline Age, years & $72(57-80)$ & $60(47-73)$ & 0.35 \\
\hline Male, n (\%) & $5(62.5)$ & $6(85.7)$ & 0.31 \\
\hline BMI & $21.4(17.7-27.9)$ & $25.2(24.0-27.8)$ & 0.47 \\
\hline ECMO to CRRT, $\mathrm{h}$ & $12(1-15)$ & $44(24-48)$ & 0.001 \\
\hline ECMO, h & $124(32-192)$ & $169(78-321)$ & 0.16 \\
\hline Systolic blood pressure, $\mathrm{mm} \mathrm{Hg}$ & $100(74-139)$ & $120(101-145)$ & 0.25 \\
\hline \multicolumn{4}{|l|}{ Past history } \\
\hline Coronary artery disease, n (\%) & $3(37.5)$ & $3(42.9)$ & 0.83 \\
\hline Type 2 diabetes, $\mathrm{n}(\%)$ & $3(37.5)$ & $2(28.6)$ & 0.71 \\
\hline CKD, n (\%) & $4(50.0)$ & $5(71.4)$ & 0.40 \\
\hline Reason for ECMO use & & & 0.17 \\
\hline Acute myocardial infarction with cardiogenic shock, n (\%) & $7(87.5)$ & $3(42.9)$ & \\
\hline Out-of-hospital cardiac arrest, n (\%) & $1(12.5)$ & $3(42.9)$ & \\
\hline \multicolumn{4}{|l|}{ Laboratory values } \\
\hline Baseline serum creatinine, mg/dl & $1.2(1.0-2.2)$ & $1.2(1.0-2.7)$ & 0.88 \\
\hline Pre-ECMO serum creatinine, $\mathrm{mg} / \mathrm{dl}$ & $3.6(2.2-4.6)$ & $2.3(1.3-3.1)$ & 0.07 \\
\hline Pre-CRRT serum creatinine, mg/dl & $3.3(3.0-4.7)$ & $3.7(1.6-5.4)$ & 0.77 \\
\hline Urine output at ECMO installation, $\mathrm{ml} / \mathrm{kg} / \mathrm{h}$ & $0.06(0-0.22)$ & $0.17(0.02-0.29)$ & 0.11 \\
\hline LVEF at admission, $\%$ & $31(20-48)$ & $23(20-25)$ & 0.26 \\
\hline White blood cell count, $\times 10^{3}$ cells $/ \mu \mathrm{l}$ & $15(12-23)$ & $9.2(6.4-14.4)$ & 0.10 \\
\hline Serum potassium, $\mathrm{mEq} / \mathrm{l}$ & $5.0(3.9-6.6)$ & $4.3(3.6-4.9)$ & 0.07 \\
\hline Hemoglobin at ECMO installation, g/dl & $9.9(8.9-11.0)$ & $13(11.4-14.6)$ & 0.01 \\
\hline Albumin, g/dl & $3.1(2.5-3.4)$ & $2.6(2.2-3.2)$ & 0.52 \\
\hline \multicolumn{4}{|l|}{ Clinical presentations } \\
\hline Inotropic equivalent dose, $\mu \mathrm{g} / \mathrm{kg} / \mathrm{min}^{\mathrm{a}}$ & $40(24-50)$ & $15(4-16)$ & 0.09 \\
\hline Use of inotropics, n (\%) & $7(87.5)$ & $5(71.4)$ & 0.44 \\
\hline CVP level at ECMO installation, $\mathrm{mm} \mathrm{Hg}$ & $17(14-18)$ & $18(14-23)$ & 0.69 \\
\hline APACHE II score at ECMO installation & $27(21-35)$ & $24(22-30)$ & 0.77 \\
\hline Average ultrafiltration rate during CRRT, $\mathrm{ml} / \mathrm{kg} / \mathrm{h}$ & $0.9(0.5-1.9)$ & $0.9(0.3-1.4)$ & 0.62 \\
\hline Average urine output during CRRT, $\mathrm{ml} / \mathrm{kg} / \mathrm{h}$ & $0.1(0.06-0.1)$ & $0.1(0.05-0.4)$ & 0.26 \\
\hline Coronary catheterization during admission, n (\%) & $4(50.0)$ & $3(42.9)$ & 0.78 \\
\hline Cardiopulmonary resuscitation during admission, n (\%) & $5(62.5)$ & $3(42.9)$ & 0.48 \\
\hline \multicolumn{4}{|l|}{ Outcome } \\
\hline Survival to weaning from ECMO, n (\%) & $3(37.5)$ & $2(28.6)$ & 0.71 \\
\hline
\end{tabular}

Numeric variables are expressed as medians with 25th-75th percentiles in parentheses.

${ }^{\mathrm{a}}$ Inotropic equivalent $=[($ dopamine + dobutamine $)+($ milrinone $\times 15)+($ epinephrine + norepinephrine + isoproterenol $) \times$ $100]$ in $\mu \mathrm{g} / \mathrm{kg} / \mathrm{min}[14]$.

with reduced survival among patients who received acute dialysis during ECMO therapy, especially those who had not undergone coronary artery bypass surgery. In our study, the interval between the initiation of ECMO and that of CRRT was shorter because of the advanced AKIN stage and age of our ECMO patients. A previous study of the impact of dialysis timing on mortality has been hampered by poor methodology and the heterogeneity of clinical variables [18].

Two studies in Asia compared early and late dialysis in septic AKI patients. Using a 24-hour cutoff point, Chou et al. [19] reported a significant benefit from early dialysis, which 
Lin et al.: Early Continuous Renal Replacement Therapy in Cardiogenic Shock Patients with Severe Acute Kidney Injury Undergoing Extracorporeal Membrane Oxygenation

Table 3. Characteristics of the long-term survivors

\begin{tabular}{lllllll}
\hline & $\begin{array}{l}\text { Age, } \\
\text { years }\end{array}$ & Gender & $\begin{array}{l}\text { Pre-ECMO } \\
\text { serum creatinine, } \\
\mathrm{mg} / \mathrm{dl}\end{array}$ & $\begin{array}{l}\text { Postserum GFR } \\
\text { 3 months after discharge, } \\
\mathrm{ml} / \mathrm{min} / 1.73 \mathrm{~m}^{2}\end{array}$ & $\begin{array}{l}\text { Duration } \\
\text { of ECMO, } \\
\mathrm{h}\end{array}$ & $\begin{array}{l}\text { Reason for } \\
\text { ECMO use }\end{array}$ \\
\hline Patient 1 & 72 & female & 4.9 & 14.37 & 192 & AMI \\
Patient 2 & 46 & male & 7.2 & 89.86 & 192 & OHCA \\
Patient 3 & 83 & female & 4.2 & $14.42^{\mathrm{a}}$ & 199 & AMI \\
Patient 4 & 72 & male & 3.4 & 36.78 & 201 & AMI \\
\hline
\end{tabular}

AMI = Acute myocardial infarction; $\mathrm{OHCA}=$ out-of-hospital cardiac arrest.

a On maintenance hemodialysis.

Fig. 1. Kaplan-Meier survival curves demonstrating cumulative patient survival in the early-dialysis (solid line) and late-dialysis (dashed line) groups ( $\mathrm{p}=0.58$ by the log-rank test).

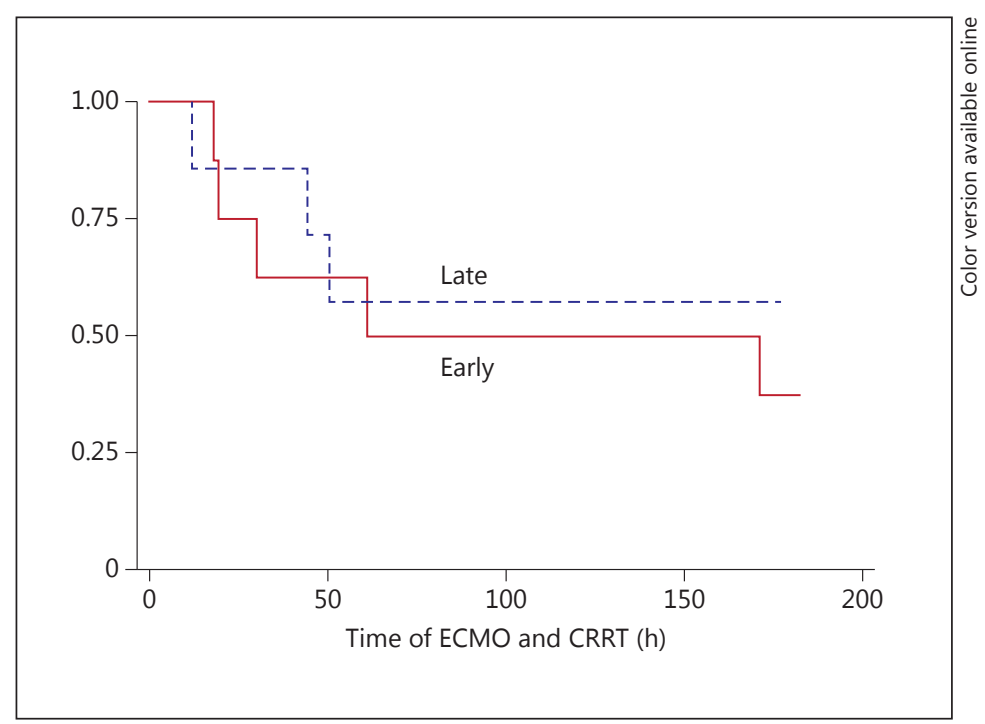

differed from the findings of a previous study that used the Risk, Injury, Failure, Loss of Function, and End-Stage Renal Disease (RIFLE) criteria [19]. However, early dialysis has demonstrated a survival benefit in animal and human studies of AKI. In an animal study, the use of CRRT reduced the inflammatory response in a piglet hemorrhage-reperfusion ECMO model [20]. Among different populations receiving abdominal surgeries, early dialysis (as defined by the RIFLE-o and -i criteria) in postsurgical AKI patients led to a significant improvement in cumulative survival compared with late dialysis (as defined by the RIFLE-R and -F criteria) [21].

A large multicenter prospective epidemiological study has shown that the initiation of CRRT $>5$ days after admission, defined as late dialysis, was associated with increased mortality, whereas serum creatinine was not [22]. Other investigators have suggested the importance of initiating CRRT during ECMO in patients in the early phases of renal dysfunction with fluid overload or inflammation [23]. In addition, Selewski et al. [24] reported that initiating CRRT before the development of a significant fluid overload may be more clinically effective than attempting fluid removal after the fluid overload has developed. Thus, the lack of a survival benefit with early dialysis in our study may be an indicator of the fact that CRRT had not been initiated early enough in our ECMO patients. 


\section{CardioRenal Medicine}

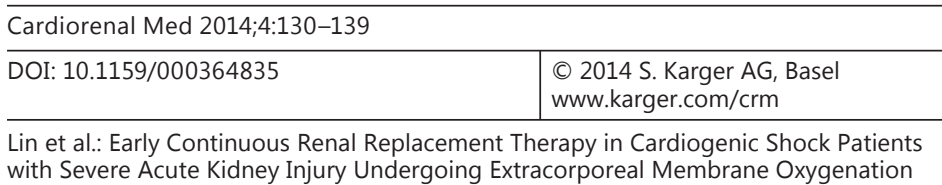

Lin et al.: Early Continuous Renal Replacement Therapy in Cardiogenic Shock Patients
with Severe Acute Kidney Injury Undergoing Extracorporeal Membrane Oxygenation

In our study, all the ECMO patients had severe AKI and were classified as AKIN stage 3, which may have contributed to the lack of a survival benefit with early dialysis. In addition, increasing evidence suggests that the use of CRRT in AKI patients should rely more on urine volume, serum $\mathrm{pH}$, and organ failure [25] than on serum creatinine levels, especially in fluid overload patients with reduced serum creatinine [26]. Furthermore, the hemofiltration dose in our patients did not exceed $35 \mathrm{ml} / \mathrm{kg} / \mathrm{h}$ because of the risk of clotting in the hollow fibers of the CRRT unit installed in the ECMO circuit, which decreased the therapeutic dose and effect of the CRRT. In practice, a $25 \%$ increase is recommended to achieve an adequate dose [27]. The findings of our study are, however, strengthened by the homogeneity of the sample of cardiogenic shock patients receiving VA-ECMO and the clear definitions of early and late dialysis, which combined the AKIN criteria and a 24-hour interval between ECMO and CRRT. We also measured serum creatinine in the survivors 3 months after discharge.

An interesting result of our study is that the survivors had a longer median duration of ECMO. It has been suggested that mortality among hospitalized critical care patients with severe disease requiring ECMO and CRRT, such as cardiogenic shock, may be as high as $66.7 \%$, which is comparable to the finding of another study of ECMO and acute dialysis in patients with a similar disease severity that reported a mortality of $70.6 \%$ [13]. Thus, a shorter duration of ECMO might be expected for nonsurvivors.

In our study, the median hemoglobin level in the early-dialysis group was statistically lower than that in the late-dialysis group. Because the hematocrit is an indicator of blood volume $[28,29]$, the fluid overload and hemodilution status of the early-dialysis group - in which none were patients with traumatic hypovolemic shock - was partially supported by a reduced urine output and lower serum creatinine before ECMO.

Certain limitations to our study must be considered. First, this was a small retrospective study, and the small sample size may have influenced the results in favor of the null hypothesis. Second, the difference in the median interval between ECMO and CRRT between the earlyand late-dialysis groups was only $32 \mathrm{~h}$, which might have limited the benefit of early dialysis because it was not initiated early enough. Third, we enrolled AKIN stage 3 acute cardiogenic shock patients only. It is possible that early-stage AKI patients requiring CRRT may receive a greater survival benefit from early dialysis [30, 31].

In conclusion, our results show that early dialysis conferred no statistically significant survival benefit in ECMO patients with severe AKI, and that the mean duration of ECMO for patients who received early dialysis, although shorter, was not significantly different from that for the late-dialysis group. Future large prospective studies are warranted to clarify our findings and further assess the survival benefit of early dialysis for early-stage AKI patients receiving ECMO.

\section{Acknowledgement}

This study was partly supported by a grant awarded to C.-Y. Huang by the National Science Council, Taiwan (ROC; NSC 99-2314-B-038-007-MY3).

\section{References}

1 Roy BJ, Rycus P, Conrad SA, Clark RH: The changing demographics of neonatal extracorporeal membrane oxygenation patients reported to the Extracorporeal Life Support Organization (ELSO) Registry. Pediatrics 2000;106:1334-1338.

- Hsu KH, Chi NH, Yu HY, Wang CH, Huang SC, Wang SS, Ko WJ, Chen YS: Extracorporeal membranous oxygenation support for acute fulminant myocarditis: analysis of a single center's experience. Eur J Cardiothorac Surg 2011;40:682-688. 


\section{CardioRenal Medicine}

\begin{tabular}{l|l}
\hline Cardiorenal Med 2014;4:130-139 \\
\hline DOI: 10.1159/000364835 & $\begin{array}{l}\text { (c) 2014 S. Karger AG, Basel } \\
\text { www.karger.com/crm }\end{array}$ \\
\hline
\end{tabular}

Lin et al.: Early Continuous Renal Replacement Therapy in Cardiogenic Shock Patients with Severe Acute Kidney Injury Undergoing Extracorporeal Membrane Oxygenation

3 Chen YS, Lin JW, Yu HY, Ko WJ, Jerng JS, Chang WT, Chen WJ, Huang SC, Chi NH, Wang CH, Chen LC, Tsai PR, Wang SS, Hwang JJ, Lin FY: Cardiopulmonary resuscitation with assisted extracorporeal life-support versus conventional cardiopulmonary resuscitation in adults with in-hospital cardiac arrest: an observational study and propensity analysis. Lancet 2008;372:554-561.

4 Tsao NW, Shih CM, Yeh JS, Kao YT, Hsieh MH, Ou KL, Chen JW, Shyu KG, Weng ZC, Chang NC, Lin FY, Huang CY: Extracorporeal membrane oxygenation-assisted primary percutaneous coronary intervention may improve survival of patients with acute myocardial infarction complicated by profound cardiogenic shock. J Crit Care 2012;27:530e1-e11.

5 Conrad SA, Rycus PT, Dalton H: Extracorporeal Life Support Registry Report 2004. ASAIO J 2005;51:4-10.

-6 Kelly RE Jr, Phillips JD, Foglia RP, Bjerke HS, Barcliff LT, Petrus L, Hall TR: Pulmonary edema and fluid mobilization as determinants of the duration of ECMO support. J Pediatr Surg 1991;26:1016-1022.

7 Foland JA, Fortenberry JD, Warshaw BL, Pettignano R, Merritt RK, Heard ML, Rogers K, Reid C, Tanner AJ, Easley KA: Fluid overload before continuous hemofiltration and survival in critically ill children: a retrospective analysis. Crit Care Med 2004;32:1771-1776.

-8 Santiago MJ, Sanchez A, Lopez-Herce J, Perez R, del Castillo J, Urbano J, Carrillo A: The use of continuous renal replacement therapy in series with extracorporeal membrane oxygenation. Kidney Int 2009;76:1289-1292.

-9 Hoover NG, Heard M, Reid C, Wagoner S, Rogers K, Foland J, Paden ML, Fortenberry JD: Enhanced fluid management with continuous venovenous hemofiltration in pediatric respiratory failure patients receiving extracorporeal membrane oxygenation support. Intensive Care Med 2008;34:2241-2247.

-10 Elahi MM, Lim MY, Joseph RN, Dhannapuneni RR, Spyt TJ: Early hemofiltration improves survival in postcardiotomy patients with acute renal failure. Eur J Cardiothorac Surg 2004;26:1027-1031.

11 Miyamoto T, Yoshimoto A, Tatsu K, Ikeda K, Ishii Y, Kobayashi T: Zero mortality of continuous veno-venous hemodiafiltration with PMMA hemofilter after pediatric cardiac surgery. Ann Thorac Cardiovasc Surg 2011; 17:352-355.

12 Vinsonneau C, Monchi M: Too early initiation of renal replacement therapy may be harmful. Crit Care 2011; 15:112.

13 Wu VC, Tsai HB, Yeh YC, Huang TM, Lin YF, Chou NK, Chen YS, Han YY, Chou A, Lin YH, Wu MS, Lin SL, Chen YM, Tsai PR, Ko WJ, Wu KD: Patients supported by extracorporeal membrane oxygenation and acute dialysis: acute physiology and chronic health evaluation score in predicting hospital mortality. Artif Organs 2010;34: 828-835.

14 Levey AS, Stevens LA, Schmid CH, Zhang YL, Castro AF 3rd, Feldman HI, Kusek JW, Eggers P, van Lente F, Greene T, Coresh J: A new equation to estimate glomerular filtration rate. Ann Intern Med 2009;150:604-612.

15 Paden ML, Warshaw BL, Heard ML, Fortenberry JD: Recovery of renal function and survival after continuous renal replacement therapy during extracorporeal membrane oxygenation. Pediatr Crit Care Med 2011;12: 153-158.

16 Rajagopal SK, Almond CS, Laussen PC, Rycus PT, Wypij D, Thiagarajan RR: Extracorporeal membrane oxygenation for the support of infants, children, and young adults with acute myocarditis: a review of the Extracorporeal Life Support Organization registry. Crit Care Med 2010;38:382-387.

17 Wu MY, Tseng YH, Chang YS, Tsai FC, Lin PJ: Using extracorporeal membrane oxygenation to rescue acute myocardial infarction with cardiopulmonary collapse: the impact of early coronary revascularization. Resuscitation 2013;84:940-945.

18 Karvellas CJ, Farhat MR, Sajjad I, Mogensen SS, Leung AA, Wald R, Bagshaw SM: A comparison of early versus late initiation of renal replacement therapy in critically ill patients with acute kidney injury: a systematic review and meta-analysis. Crit Care 2011;15:R72.

19 Chou YH, Huang TM, Wu VC, Wang CY, Shiao CC, Lai CF, Tsai HB, Chao CT, Young GH, Wang WJ, Kao TW, Lin SL, Han YY, Chou A, Lin TH, Yang YW, Chen YM, Tsai PR, Lin YF, Huang JW, Chiang WC, Chou NK, Ko WJ, Wu KD, Tsai TJ: Impact of timing of renal replacement therapy initiation on outcome of septic acute kidney injury. Crit Care 2011;15:R134.

20 Mu TS, Palmer EG, Batts SG, Lentz-Kapua SL, Uyehara-Lock JH, Uyehara CF: Continuous renal replacement therapy to reduce inflammation in a piglet hemorrhage-reperfusion extracorporeal membrane oxygenation model. Pediatr Res 2012;72:249-255.

-21 Shiao CC, Wu VC, Li WY, Lin YF, Hu FC, Young GH, Kuo CC, Kao TW, Huang DM, Chen YM, Tsai PR, Lin SL, Chou NK, Lin TH, Yeh YC, Wang CH, Chou A, Ko WJ, Wu KD: Late initiation of renal replacement therapy is associated with worse outcomes in acute kidney injury after major abdominal surgery. Crit Care 2009;13:R171.

22 Bagshaw SM, Uchino S, Bellomo R, Morimatsu H, Morgera S, Schetz M, Tan I, Bouman C, Macedo E, Gibney N, Tolwani A, Oudemans-van Straaten HM, Ronco C, Kellum JA: Timing of renal replacement therapy and clinical outcomes in critically ill patients with severe acute kidney injury. J Crit Care 2009;24:129-140.

-23 Ricci Z, Ronco C: Renal replacement therapy in the critically ill: getting it right. Curr Opin Crit Care 2012;18: 607-612.

24 Selewski DT, Cornell TT, Blatt NB, Han YY, Mottes T, Kommareddi M, Gaies MG, Annich GM, Kershaw DB, Shanley TP, Heung M: Fluid overload and fluid removal in pediatric patients on extracorporeal membrane oxygenation requiring continuous renal replacement therapy. Crit Care Med 2012;40:2694-2699.

25 Ostermann M, Chang RW: Correlation between parameters at initiation of renal replacement therapy and outcome in patients with acute kidney injury. Crit Care 2009;13:R175. 


\section{CardioRenal Medicine}

Lin et al.: Early Continuous Renal Replacement Therapy in Cardiogenic Shock Patients with Severe Acute Kidney Injury Undergoing Extracorporeal Membrane Oxygenation

-26 Macedo E, Bouchard J, Soroko SH, Chertow GM, Himmelfarb J, Ikizler TA, Paganini EP, Mehta RL: Fluid accumulation, recognition and staging of acute kidney injury in critically-ill patients. Crit Care 2010;14:R82.

27 Kellum JA, Ronco C: Dialysis: results of RENAL - what is the optimal CRRT target dose? Nat Rev Nephrol 2010; 6:191-192.

-28 Steuer RR, Leypoldt JK, Cheung AK, Harris DH, Conis JM: Hematocrit as an indicator of blood volume and a predictor of intradialytic morbid events. ASAIO J 1994;40:M691-M696.

29 Schneditz D, Putz-Bankuti C, Ribitsch W, Schilcher G: Correction of plasma concentrations for effects of hemoconcentration or hemodilution. ASAIO J 2012;58:160-162.

30 Carl DE, Grossman C, Behnke M, Sessler CN, Gehr TW: Effect of timing of dialysis on mortality in critically ill, septic patients with acute renal failure. Hemodial Int 2010;14:11-17.

-31 Ricci Z, Ronco C: Year in review 2009: Critical Care - nephrology. Crit Care 2010;14:241.

\section{Erratum}

In the article by Billings FT, Yu C, Byrne JG, Petracek MR and Pretorius M, entitled 'Heme oxygenase-1 and acute kidney injury following cardiac surgery' [Cardiorenal Med 2014;4:12-21], Frederic T. Billings should read Frederic T. Billings IV. 